científico nacional (era possível marcar mais de uma opção) foram a medicina, com $52 \%$ dos votos, o investimento em energias alternativas ( $37 \%$ dos votos) e a agricultura ( $27 \%$ dos votos). Mudanças climáticas e exploração dos recursos da Amazônia aparecem logo em seguida.

Um ponto que chamou a atenção dos pesquisadores foi a piora na avaliação dos brasileiros sobre a ciência no país: apenas $12 \%$ consideram a ciência nacional avançada, enquanto $43 \%$ dos entrevistados a classificam como atrasada. Estes índices são piores do que os das enquetes anteriores. $\mathrm{Na}$ enquete de 2010 , $20 \%$ consideravam a ciência avançada e $28 \%$ atrasada. Yurij Castelfranchi, professor da Universidade Federal de Minas Gerais (UFMG) e um dos organizadores do estudo, aponta duas razões para isso: "De um lado, é óbvio que a maioria dos brasileiros percebeu claramente 0 impacto dos cortes no orçamento da educação, das universidades $e$ da pesquisa, que foi se agravando desde meados do governo Dilma. De outro lado, esses indicadores (avaliação da qualidade do funcionamento de uma instituição, grau de confiança em políticos e atores institucionais) não dependem tanto do conhecimento sobre o assunto, mas, principalmente, refletem a insatisfação e a desconfiança das pessoas em geral", avalia.

USOS DO ESTUDO O estudo contém dados importantes para todos que trabalham com a produção e a divulgação de conhecimento científico no país, como aponta Moreira. Segundo ele, "a comunicação pública da ciência envolve a interação entre quem faz ciência e o público, por isso todas as pessoas que trabalham com comunicação científica - em museus de ciência, pesquisadores da área, divulgadores, jornalistas de ciência - poderiam se beneficiar dessa publicação". 0 pesquisador elege ainda professores de ciência, pesquisadores de modo geral e formuladores de políticas públicas como público-alvo do livro. Castelfranchi concorda, sugerindo que uma parceria com o Ministério da Educação (MEC), o MCTIC e outras instituições científicas seria importante "de um lado, para elaborar pesquisas em conjunto que incluam mais variáveis que auxiliem a avaliação do impacto de práticas ou políticas de divulgação. De outro, para mostrarmos as implicações práticas de nossos dados, que são muitas e podem contribuir para inovar as políticas de inclusão e a divulgação científica", finaliza.

Raphaela Velho
Meio Ambiente

\section{Aproveitamento de resíduos do setor sucroalcooleiro desafia empresas e pesquisadores}

O setor sucroalcooleiro é um dos segmentos mais importantes da economia brasileira. Segundo dados da União da Indústria de Cana-de-Açúcar (Unica), o Brasil é o maior produtor mundial de cana de açúcar, com cerca de 630 milhões de toneladas processadas na safra $2014 / 2015$, gerando uma riqueza equivalente a US\$ 43 bilhōes, cerca de $2 \%$ do PIB brasileiro. Apenas no setor produtivo, são 900 mil empregos formais diretos e outros $70 \mathrm{mil}$ produtores rurais independentes. No entanto, paralelamente à geração de riquezas e empregos, o setor é responsável por impactos ambientais importantes, pelo uso intensivo de recursos naturais e pela produção de grandes quantidades de resíduos. Nos $108.706,47 \mathrm{~km}^{2}$ com cana plantada no Brasil em 2015 (safra 2015/2016), equivalente a quase cinco vezes a área do estado de Sergipe, foram produzidos mais de 30 bilhões de litros de álcool e 34 milhôes de toneladas de açúcar. Em contrapartida, foram gerados de 10 a 14 litros de vinhaça para cada litro 
